УДК 378.147

DOI: 10.37128/2520-6168-2021-2-2

Vol. 113, No 2 / 2021

\title{
AUTOMATED TECHNOLOGICAL PROJECTION OF CLASSIFICATION PROCESSES OF DRY DISPERSIVE MATERIALS
}

\author{
Ivan Sevostianov, Doctor of Technical Sciences, Full Professor \\ Oleksii Tokarchuk, Ph.D., Associate Professor \\ Maryna Pidlypna, Post-graduate Student \\ Vinnytsia National Agrarian University
}

\author{
Севостьянов Іван Вячеславович, д.т.н., професор \\ Токарчук Олексій Анатолійович, к.т.н., доцент \\ Підлипна Марина Петрівна, аспірант \\ Вінницький національний аграрний університет
}

\begin{abstract}
Processes of classification (separation) of dry and damp dispersive materials are wide spread in metallurgy, construction, agriculture, in chemical, food, processing industry and in other branches. Therefore, constructors and technologists pay a lot of attention for rationalization of these processes and equipment for their realization in direction of increase of productivity and quality of classification, reliability of machines, decrease of power-consuming. In last decades in Ukraine with development of small and middle farming enterprises there is a tendency of increase of variety of grain raw materials by kinds, grades, humidity, sizes, mass, density and volume of particles. All this should consider food and processing enterprises which often work in quite intensive regime in a period of harvest. So, in last time there become more strong demands to efficiency of technological preparation of processes classification for selection of most rational method, equipment and regimes of processing with consideration of parameters of raw materials and demands of further technological processes (grinding, mixing, heating, cooking, frying etc). Because of that, there will be useful a method of automated technological projection of classification processes of dry dispersive materials, proposed in this article. The method allows to elaborate most effective technology of classification with consideration of volume of output program, time for its fulfilment, geometrical and structural-mechanical properties of processed material, characteristics of available equipment for classification and criterions of efficiency of elaborated technology - productivity and specified operational expenses for its realization. The method can be used as a base for elaboration of a computer program of automated synthesis and analysis of rational technological processes of classification of grain raw materials.
\end{abstract}

Key words: classification, automated technological projection, analysis and synthesis, dry dispersive materials. F. 9. Fig. 1. Ref. 18.

\section{Problem formulation}

Improvement of processes classification (separation, division) for increase of their productivity, number of classification ranges of processed material, reliability and versatility of the using equipment, decrease of operational expenses is an actual task for metallurgy, construction, agriculture, chemical, food, processing industry and for other branches, where the classification processes are wide spread. At the enterprises for grain processing in a period of harvest and at the building sites there can arise necessity of processing of big volumes of dispersive materials from different suppliers, in limited time and with provision of a number of qualitative and quantitative characteristics of the working process including it high economic efficiency. In such situations for avoiding of upsetting of the production tasks and for selection of an optimal variant of technology and machines for its fulfillment there is useful a method of the automated analysis and synthesis of the technological processes classification of dry and damp dispersive materials.

\section{Analysis of last researches and publications}

In the specialized literature on automation of technological projection and on automated production processes in food production [1-7] are presented mainly wordy descriptions of sequence of the projection, recommendations for elaboration of schemes of automation and selection of apparatus and devices for automated control of technological processes and equipment. 


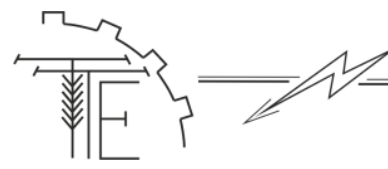

Versatile methods of automated synthesis and analysis for projection of technological processes of mechanical processing of machine building enterprises are examined in the work [8]. There is presented a structure of systems of automated projection of these processes, is given a notion about systemic attack methods, a wordy description of a sequence of the technological projection, stages of mathematic modeling and graphic presentation of technological processes (but without of corresponding formulas or listings for its program realization). The methods of optimization of technology of mechanical processing (productivity and cost value) are examined in the work in detail, but fulfillment of optimization for classification processes as well as their automated analysis and synthesis have some possibilities in comparison with the processes of mechanical processing (later are more complex and depend from quite other working parameters).

The same one can say about the work [9], where is presented a sequence of technological projection of technological processes for NC-machines and examples of its utilization for processing of standard details. But realization of this technology is fulfilled on basis of ready programmed means machines NC-system and standard built-in commands.

Foundations of automated projection of technological processes of assemblage are presented in the work [10]. In particular there are examined: demands of accuracy parameters of products and methods of their provision, means of realization of automated assemblage, arrangement schemes of flexible production processing complexes, equations for determination of time expenses for realization of working processes and parameters of their reliability, structural automation schemes, schemes of databases and control systems. All these materials can be used as a reference points for elaboration of sequence of automated projection of classification processes.

Structure of automated systems of technological projection in machine building, classifications of these systems, methods of their projection, including the methods, that realized with help of versatile computer programs of automated projection are examined in the work [11]. Also, recommendations for elaboration of control programs for NC-machines, automated projection of assemblage processes, means of technological equipment and products design with automated determination their geometrical characteristics and mass are presented in the work, but there are absent concrete examples of computer realization of the proposed recommendations.

Principles and structure of creation of automated projection systems of technological processes of machine building production are elaborated in the work [12]. There is proposed a method of elaboration of new technological processes on basis of standard technologies, classifications of details, information data bases, a mathematic provision for technological projection, including evaluation and optimization of variants of technological solutions by productivity, cost price, using of working space, tools and appliances. A linguistic and program provision for automated projection is presented in the work at a level of wordy descriptions. The work contains information about modern professional systems of automated projection of technological processes and tendencies of their improvement. On the hole, the work is the most complete source for automated preparation of machine building production.

Formulas for calculation of main efficiency parameters of assemblage technological processes for different types of production are presented in the work [13] of author of this article. But these formulas demand of some corrections before their utilization for projection of technologies of classification processes.

One more author's work [14] holds recommendations for elaboration of a products database that are planned for manufacturing, including production tasks, databases with standard technologies of processing and assemblage that were realized early at this enterprise, available equipment, tools and appliances of the enterprise. There is presented a sequence of an automated production with formulas for selection of a base technological process and its correction with consideration of actual parameters of the product and the production task, formulas and conditions for rational selection of equipment, tools and appliances, for comparison of several possible variants of synthesized technological processes and determination of the most effective variant by productivity and cost price. These formulas and conditions also can be partially used in given research.

\section{Aim of research}

Elaboration of a method of automated technological projection of classification processes of dry dispersive materials with consideration of known methods of automated projection, using in other branches and with examination of features and characteristics of classification processes. There should be foreseen possibility of realization of the method with help of a computer program. 
Vol. 113, No 2 / 2021

\section{Results of research}

There is a block-scheme of an algorithm of the proposed method of automated technological projection of classification processes of dry dispersive materials, presented at the Fig. 1.

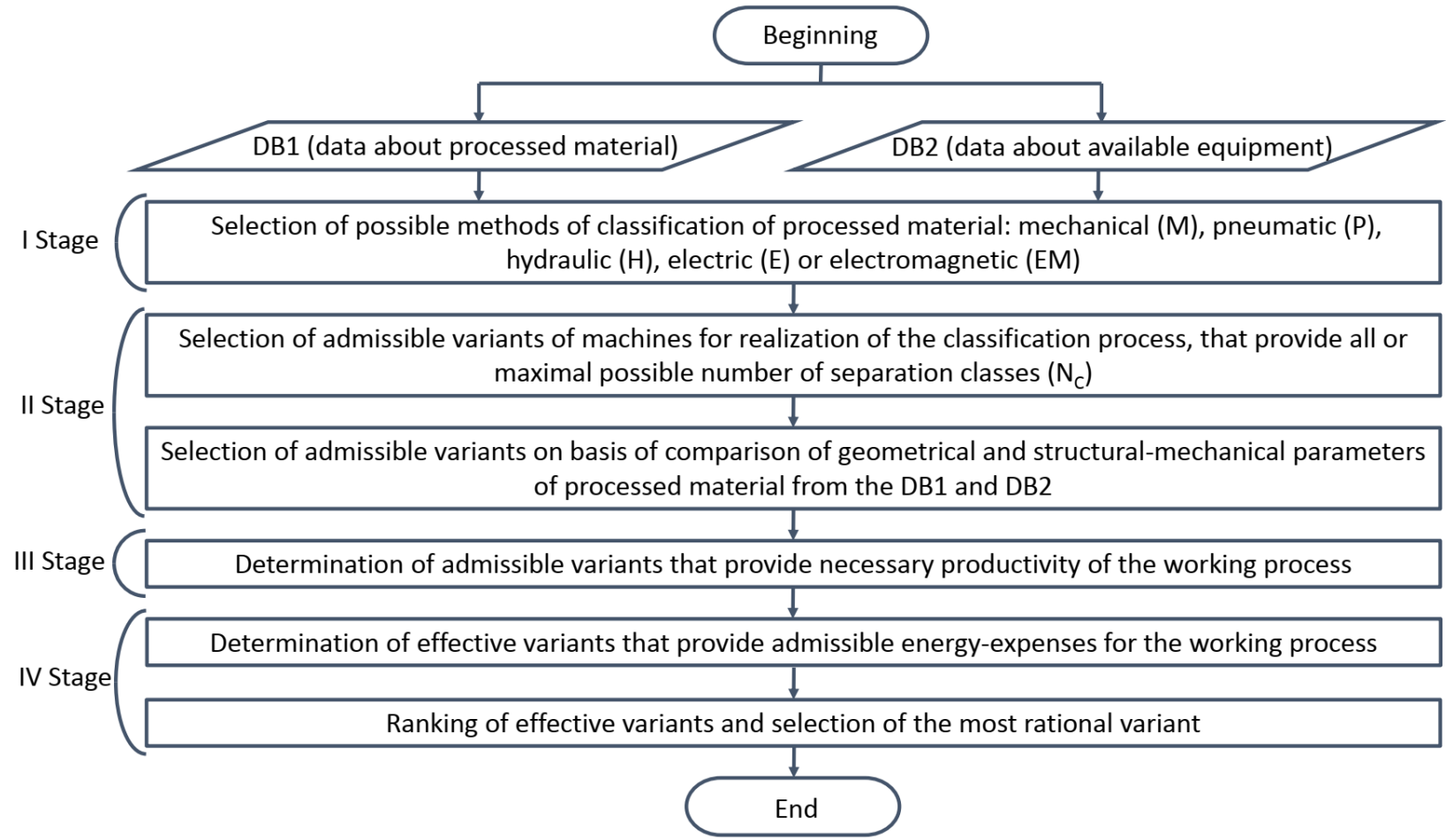

Fig. 1. The block-scheme of an algorithm of the proposed method of automated technological projection of classification processes of dry dispersive materials

All necessary information for automated technological projection of classification processes can be presented in two main databases: the database with information about production task $(D B 1)$ and the database with information about available equipment for classification (DB2) [15].

In $D B 1$ are collected data about kind of processed raw material (for example, $M 1$ - wheat, $M 2$ - barley; $M 3$ - rye; $M 4$ - peas, ...), its grade $(G 1, G 2, G 3, \ldots)$, maximal and minimal ratios of length to diameter for particles of raw material $\left(L_{\max } / D_{\max }, L_{\min } / D_{\min }\right)$, maximal and minimal humidity $\left(H_{\max }, H_{\min }\right)$, mass $\left(M_{\max }, M_{\min }\right)$, density $\left(D e_{\max }, D e_{\min }\right)$, volume $\left(V_{\max }, V_{\min }\right)$ and form $\left(F S\right.$ - spherical, $F O$ - oblong) of particles, general mass $\left(M_{G}\right)$ and volume $\left(V_{G}\right)$ of processed material, time $(T)$ for fulfillment of the production task, the number of classes (ranges) of separation $\left(N_{C}\right)$, admissible expenses $\left(E_{G}\right)$ for realization of the classification process $[13,14,16]$.

In $D B 2$ are collected data about productivity of machines for classification [17] in $\mathrm{kg} / \mathrm{s}$ or in $\mathrm{m}^{3} / \mathrm{s}$ : rotary screens $\left(P_{S R 1}, P_{S R 2}, \ldots\right)$, vibrating screens $\left(P_{S V 1}, P_{S V 2}, \ldots\right)$, gyratory screens $\left(P_{S G 1}, P_{S G 2}, \ldots\right)$, double-deck screens $\left(P_{S D D 1}, P_{S D D 2}, \ldots\right)$, electromagnetic vibrating screens $\left(P_{S E V 1}, P_{S E V 2}, \ldots\right)$, grain cleaners $\left(P_{G C 1}, P_{G C 2}, \ldots\right)$, centrifugal separators $\left(P_{S C l}, P_{S C 2}, \ldots\right)$, winnowing machines $\left(P_{W M 1}, P_{W M 2}, \ldots\right)$, hydraulic separators $\left(P_{S H 1}, P_{S H 2}, \ldots\right)$, electric classifiers $\left(P_{C E 1}, P_{C E 2}, \ldots\right)$; parameters of particles of raw material (see above), which can classify each kind of machines: $P_{S R I}\left(L_{\max } / D_{\max }, L_{\min } / D_{\min }, H_{\max }, H_{\min }, M_{\max }, M_{\min }, D e_{\max }, D e_{\min }, V_{\max }, V_{\min }, F S\right.$ or $\left.F O, N_{C}\right), P_{S R 2}\left(L_{\max } / D_{\max }\right.$, $L_{\min } / D_{\min }, H_{\max }, H_{\min }, M_{\max }, M_{\min }, D e_{\max }, D e_{\min }, V_{\max }, V_{\min }, F S$ or $\left.F O, N_{C}\right), \ldots$; specific operational expenses for each kind of machines in $Z / \mathrm{kg}$ or in $\mathrm{Z} / \mathrm{m}^{3}\left(O_{E-P S R}, O_{E-P S R 2}, \ldots, O_{E-P S V I}, O_{E-P S V 2}, \ldots, O_{E-P S R I}, O_{E-P S R 2}, \ldots\right)$.

At the first stage of the technological projection with consideration of information of $D B 1$ there is realized selection of possible methods of classification of processed material $[17,18]$ : mechanical $(M)$, pneumatic $(P)$, hydraulic $(H)$, electric $(E)$, electromagnetic $(E M)$. For example, the mechanical method with utilization of rotary screens, vibrating screens, gyratory screens, double-deck screens or electromagnetic vibrating screens is most effective for classification of grain raw materials [17], whereas, the hydraulic method is rational for classification of peas [17].

There can be used such ratios for programming of this stage of projection

$$
M 1 \rightarrow M, E M ; M 2 \rightarrow M, E M ; M 3 \rightarrow M, E M ; M 4 \rightarrow H ; G 1 \rightarrow M ; G 2 \rightarrow M ; G 3 \rightarrow E ; \ldots
$$




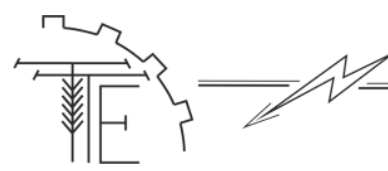

At the second stage of the projection there is carried out a selection of appropriate machines for realization of given classification process on basis of comparison of geometrical and structural-mechanical parameters of processed material from the $D B 1$ and $D B 2$. First of all, there should be selected the machines that provide fulfillment of all number of separation classes $\left(N_{C}\right)$.

Conditions for realization of this selection can present in formalizing appearance as

$$
\text { IF } N_{C . S R l} \geq N_{C} \text { THEN SRl } \in S_{A V} ; \ldots ; \text { IF } N_{C . S V l} \geq N_{C} \text { THEN } S V 1 \in S_{A V l} ; \ldots
$$

where $N_{C . S R I}, . ., N_{C . S V 1}, \ldots$ - number of classes of separation, that provide available machines of the enterprise; $S_{A V I}$ - the first set of admissible variants of equipment. maximal $N_{C}$ :

If machines, that realize all these stages are absent there is need to select equipment for fulfillment of

$$
\text { SELECTION OF MAX FROM } N_{C . S R 1}, N_{C . S R 2}, \ldots, N_{C . S V l}, N_{C . S V 2}, \ldots V_{i}\left(N_{\max }\right) \in S_{A V l},
$$

where $V_{i}\left(N_{C \max }\right)$ - a variant of equipment with maximal $N_{C}$ (if the $S_{A V}$ after check of conditions (2) is empty, there should be several variants with maximal $N_{C}$ ).

Also at this stage for variants from the $S_{A V l}$ is checked up fulfillment of ratios

$$
\begin{aligned}
& P_{1}\left(L_{\max 1} / D_{\max 1}, L_{\min 1} / D_{\min 1}, H_{\max 1}, H_{\min 1}, M_{\max 1}, M_{\min 1}, D e_{\max 1}, D e_{\min 1}, V_{\max 1}, V_{\min 1}, F S_{1} \text { or } F O_{1}\right) \rightarrow \\
& \rightarrow\left(L_{\max } / D_{\max }, L_{\min } / D_{\min }, H_{\max }, H_{\min }, M_{\max }, M_{\min }, D e_{\max }, D e_{\min }, V_{\max }, V_{\min }, F S \text { or } F O\right) \\
& P_{2}\left(L_{\max 2} / D_{\max 2}, L_{\min 2} / D_{\min 2}, H_{\max 2}, H_{\min 2}, M_{\max 2}, M_{\min 2}, D e_{\max 2}, D e_{\min 2}, V_{\max 2}, V_{\min 2}, F S_{2} \text { or } F O_{2}\right) \rightarrow \\
& \rightarrow\left(L_{\max } / D_{\max }, L_{\min } / D_{\min }, H_{\max }, H_{\min }, M_{\max }, M_{\min }, D e_{\max }, D e_{\min }, V_{\max }, V_{\min }, F S \text { or } F O\right) \\
& P_{n}\left(L_{\max . n} / D_{\max . n}, L_{\text {min.n }} / D_{\text {min.n }}, H_{\max . n}, H_{\operatorname{min.} .}, M_{\max . n}, M_{\min . n}, D e_{\max . n}, D e_{\min . n}, V_{\max . n}, V_{\min . n}, F S_{n} \text { or } F O_{n}\right) \rightarrow \\
& \rightarrow\left(L_{\max } / D_{\max }, L_{\min } / D_{\min }, H_{\max }, H_{\min }, M_{\max }, M_{\min }, D e_{\max }, D e_{\min }, V_{\max }, V_{\min }, F S \text { or } F O\right) \text {, } \\
& \text { where } P_{1}\left(L_{\max 1} / D_{\max 1}, L_{\min 1} / D_{\min 1}, \ldots ; P_{2}\left(L_{\max 2} / D_{\max 2}, L_{\min 2} / D_{\min 2}, \ldots, P_{n}\left(L_{\max . n} / D_{\max . n}, L_{\min . n} / D_{\min . n}, \ldots{ }^{-}\right.\right.\right.
\end{aligned}
$$

variants of machines from the $S_{A V l}$ and their parameters.

For variants $V_{i}, V_{j}, \ldots, V_{k}$, which correspond to conditions (4) are carried out operations

$$
V_{i} \in S_{A V 2}, V_{j} \in S_{A V 2}, \ldots, V_{k} \in S_{A V 2} .
$$

At the third stage amidst of machines from the $S_{A V 2}$ there is determined an equipment, that provides necessary productivity of the working process. For these machines should be fulfilled conditions

$$
P_{i} \geq \frac{M_{G}}{T} \text { or } P_{i} \geq \frac{V_{G}}{T},
$$

where $P_{i}$ - mass or volumetric productivity of $i$-machine from the $S_{A V 2}$, selected after the second stage.

For variants $V_{i}, V_{j}, \ldots, V_{k}$, which correspond to conditions (6) are carried out operations

$$
V_{i} \in S_{A V 3}, V_{j} \in S_{A V 3}, \ldots, V_{k} \in S_{A V 3},
$$

where $S_{A V l}$ - the set of admissible variants of equipment, that is formed by results of the check of conditions (6).

In course of the fourth stage there is fulfilled a ranking of the equipment that was selected at previous stage the most energy-effective machines. Herewith are used conditions

$$
O_{i} \leq \frac{E_{G}}{M_{G}} \text { or } O_{i} \leq \frac{E_{G}}{V_{G}}
$$

where $O_{i}$ - specific operational expenses for $i$-machine, selected after the third stage.

From the equipment, that satisfies to conditions (8) is formed the set $S_{E V}$ of effective variants:

$$
V_{i} \in S_{E V}, V_{j} \in S_{E V}, \ldots, V_{k} \in S_{E V} \text {. }
$$

Amidst the machines of the set $S_{E V}$ is picked out the most rational variant.

On basis of the proposed method there can be elaborated a computer program of the automated synthesis and analysis of technological classification processes of dry dispersive materials.

\section{Conclusions}

1. There are problems of quick selection optimal variant of technological process of classification of damp or dry dispersive materials (grains, building materials) and equipment for their realization with consideration of different quantitative and qualitative criterions.

2. There is proposed a method of the automated synthesis and analysis of technological processes and equipment for classification of dispersive materials, which allows on basis of information about production task and available equipment to determine an optimal method of working process realization and to select machine with provision of necessary quality of classification, maximal productivity and minimal energy expenses. 


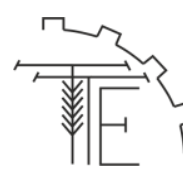

Vol. 113, No 2 / 2021

3. The proposed method can be used as a basis for elaboration of a computer program of the automated synthesis and analysis of technological classification processes of dry dispersive materials.

\section{References}

[1] Elperin, I.V. (2017). Avtomatyzatsiia vyrobnychykh protsesiv [Automation of production processes]. Kyiv : Lira. [in Ukrainian].

[2] Syniehlazov, V.M., Serheiev, I.Iu. (2015). Avtomatyzatsiia tekhnolohichnykh protsesiv [Automation of technological processes]. Kyiv : Lira. [in Ukrainian].

[3] Vasylkivskyi, I.S., Fedynets, V.O., Yusyk, Ya.P. (2020) Vykonavchi prystroi system avtomatyzatsii [Executive devices of automation systems]. Lviv : Lvivska politekhnika. [in Ukrainian].

[4] Ivanyshyn, T.V., Mazepa, S.S. (2019). Osnovy avtomatyky ta avtomatyzatsiia vyrobnychykh protsesiv lisovykh ta derevoobrobnykh pidpryiemstv [Foundations of automatics and automation of production processes of forest and timber enterprises]. K.: Mahnoliia. [in Ukrainian].

[5] Trehub, V.H.(2019). Proektuvannia system avtomatyzatsii [Projection of automation systems]. Kyiv: Lira. [in Ukrainian].

[6] Yacenko, V.F., Sokolov, V.A., Sivakova, L.B. (1983). Osnovy avtomatizacii tekhnologicheskih processov pishchevyh proizvodstv [Foundations of automation of technological processes of food productions]. Moscow: Legkaya i pishchevaya promyshlennost'. [in Russian].

[7] Borodin, I.F., Nedil'ko, N.M. (1986). Avtomatizaciya tekhnologicheskih processov [Automation of technological processes]. Moscow: Agropromizdat. [in Russian].

[8] Akulovich, L.M., Sheleg, V.K. (2012). Osnovy avtomatizirovannogo proektirovaniya tekhnologicheskih processov $v$ mashinostroenii [Foundations of automated projection of technological processes in machine building]. Minsk : Novoe znanie ; Moscow: INFRA-M. [in Russian].

[9] Samsonov, Y.I., Anisimov, O.N., Karev, E.A., Bulygina, M.N., Zlobin, P.I. (2000) Avtomatizirovannoe proektirovanie tekhnologicheskih processov mekhanicheskoj obrabotki zagotovok na stankah s CHPU [Automated projection of technological processes of blanks machining at NC-machines]. Ul'yanovsk: Ul'yanovsk State Technical University. [in Russian].

[10] Koval'chuk, E.R., Kosov, M.G., Mitrofanov, V.G. (1999). Osnovy avtomatizacii mashinostroitel'nogo proizvodstva [Foundations of automation of machine building production]. Moscow : Mashinostroenie. [in Russian].

[11] Timiryazev, V.A., Skhirtladze, A.G., Solnyshkin, N.P. (2016). Tekhnologiya proizvodstva $i$ avtomatizirovannoe proektirovanie tekhnologicheskih processov $v$ mashinostroenii [Technology of production and automated projection of technological processes in machine building]. Pskov: Pskovskij gosudarstvennyj universitet. [in Russian].

[12] Kondakov, A.I. (2007). SAPR tekhnologicheskih processov [CAD of technological processes]. Moscow: Izdatel'skij centr «Akademiya». [in Russian].

[13] Sevostianov, I. V. (2015). Racional'na poslidovnist' proektuvannja tehnologichnih procesiv skladannja [Rational consecution of projection of assembly technological processes]. Naukovi praci Vinnic'kogo nacional'nogo tehnichnogo universitetu, 1, 1-5. [in Ukrainian].

[14] Sevostianov, I. V. (2018). Avtomatizacija proektuvannja tehnologichnih procesiv mehanichnoï obrobki ta skladannja [Automation of projection of technological processes of mechanical processing and assembly]. Visnik mashinobuduvannja ta transportu, 1(7), 112-120. [in Ukrainian].

[15] Sevostianov, I., Kravets, S., Pidlypna, M. (2020). Use of criterian synthesis and analysis for modernization of objects of machine building production. Engineering, Energy, Transport AIC, 2(109), 88-96. [in English].

[16] Sevostianov, I. V. (2021). Protsesy ta obladnannia dlia vibroudarnoho filtruvannia volohykh dyspersnykh seredovyshch : monohrafiia [Processes and equipment for vibro-blowing filtration of damp dispersive materials]. Vinnytsia : VNAU [in Ukrainian].

[17] Cherevko, O.I., Poperechnyi, A.M. (2014). Protsesy ta aparaty kharchovykh vyrobnytstv [Processes and apparatuses of food productions]. Kharkiv: Svit knyh [in Ukrainian].

[18] Sevostianov, I., Pidlypna, M. (2020). Model of optimization of functioning of modern polygraphic and publishing complexes. Engineering, Energy, Transport AIC, 4(111). 90-99. [in English].

\section{Список використаних джерел}

1. $\quad$ Ельперін І. В. Автоматизація виробничих процесів. К. : Ліра, 2017. 378 с.

2. Синєглазов В. М., Сергеєв І. Ю. Автоматизація технологічних процесів. К. : Ліра, 2015. 444 с.

3. Васильківський І. С., Фединець В. О., Юсик Я. П. Виконавчі пристрої систем автоматизації. Львів : Львівська політехніка, 2020. 220 с.

4. Іванишин Т. В., Мазепа С. С. Основи автоматики та автоматизація виробничих процесів лісових 
та деревообробних підприємств. К.: Магнолія, 2019. 354 с.

5. Трегуб В. Г. Проектування систем автоматизації. К. : Ліра, 2019. 344 с.

6. Яценко В. Ф., Соколов В. А., Сивакова Л. Б. Основы автоматизации технологических процессов пищевых производств. М.: Легкая и пищевая промышленность, 1983. 400 с.

7. Бородин И. Ф., Недилько Н. М. Автоматизация технологических процессов. М.: Агропромиздат, 1986. 368 с.

8. Акулович Л. М., Шелег В. К. Основы автоматизированного проектирования технологических процессов в машиностроении: учеб. пособие. Минск : Новое знание ; М. : ИНФРА-М, 2012. 488 с.

9. Самсонов Ю. И., Анисимов О. Н., Карев Е. А., Булыгина М. Н., Злобин П. И. Автоматизированное проектирование технологических процессов механической обработки заготовок на станках с ЧПУ. Ульяновск: УлГТУ, 2000. 84 с.

10. Ковальчук Е. Р., Косов М. Г., Митрофанов В. Г. Основы автоматизации машиностроительного производства. М. : Машиностроение, 1999. 312 с.

11. Тимирязев В. А., Схиртладзе А. Г., Солнышкин Н. П. Технология производства и автоматизированное проектирование технологических процессов в машиностроении. Псков: Псковский государственный университет, 2016. 334 с.

12. Кондаков А. И. САПР технологических процессов. М.: Издательский центр «Академия», 2007.272 с.

13. Севостьянов І. В. Раціональна послідовність проектування технологічних процесів складання. Наукові праці Вінницького національного технічного університету, 2015. №1. С. 1-5.

14. Севостьянов I. В. Автоматизація проектування технологічних процесів механічної обробки та складання. Вісник машинобудування та транспорту, 2018. №1 (7). С. 112-120.

15. Sevostianov I., Kravets S., Pidlypna M. Use of criterial synthesis and analysis for modernization of objects of machine building production. Engineering, Energy, Transport AIC, 2020. №2 (109). С. 88-96.

16. Севостьянов I. В. Процеси та обладнання для віброударного фільтрування вологих дисперсних середовищ : монографія. Вінниця : ВНАУ, 2021. 184 с. ISBN 978-966-949-795-6.

17. Черевко О.І., Поперечний А.М. Процеси та апарати харчових виробництв. Х.: Світ книг, 2014.495 с.

18. Sevostianov I., Pidlypna M. Model of optimization of functioning of modern polygraphic and publishing complexes. Engineering, Energy, Transport AIC, 2020. №4 (111). C. 90-99.

\section{АВТОМАТИЗОВАНЕ ТЕХНОЛОГІЧНЕ ПРОЕКТУВАННЯ ПРОЦЕСІВ КЛАСИФІКАЦІЇ СУХИХ ДІСПЕРСНИХ МАТЕРІАЛІВ}

Прочеси класифікації (поділу) сухих та вологих дисперсних матеріалів поширені в металургї, будівництві, сільському господарстві, в хімічній, харчовій, переробній промисловості та в інших галузях. Тому конструктори та технологи велику увагу приділяють раціоналізації ц̧их процесів $i$ обладнання для їх реалізачї в напрямку підвищення продуктивності та якості класифікацї, надійності машин, зниження енергоємності. В останні десятиліття в Украӥні з розвитком малих $i$ середніх фермерських господарств спостерігається тенденція збільшення різноманітності зернової сировини за видами, сортами, вологістю, розмірами частинок, їх масою, густиною та об'ємом. Все ие слід враховувати на підприємствах харчової та переробної промисловості, які в період збору врожаю часто працюють в досить інтенсивному режимі. Таким чином, останнім часом підвишуються вимоги до ефективності технологічної підготовки процесів класифікації для вибору найбільщ раціонального методу, обладнання та режимів обробки з урахуванням параметрів сировини $і$ вимог подальщих технологічних процесів (подрібнення, перемішування, нагрівання, варіння, смаження і т. д.). У зв'язку з ичим, буде корисним метод автоматизованого технологічного проектування процесів класифікації сухих дисперсних матеріалів, пропонований в даній статті. Метод дозволяє розробити найбільш ефективну технологію класифікації з урахуванням обсягу виробничого завдання, часу його виконання, геометричних та структурно-механічних властивостей оброблюваного матеріалу, характеристик наявного обладнання для класифікації та критерї̈в ефективності розробленої технологї продуктивності $і$ заданих операційних витрат на ї̈ реалізацію. Метод може бути використаний як основа для розробки комп'ютерної програми автоматизованого синтезу та аналізу раціональних технологічних процесів класифікації зернової сировини.

Ключові слова: класифікація, автоматизоване технологічне проектування, аналіз та синтез, сухі дисперсійні матеріали.

Ф. 9. Рuс. 1. Лim. 18. 


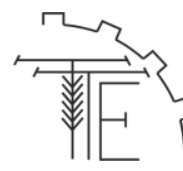

\section{АВТОМАТИЗИРОВАННОЕ ТЕХНОЛОГИЧЕСКОЕ ПРОЕКТИРОВАНИЕ ПРОЦЕССОВ КЛАССИФИКАЦИИ СУХИХ ДИСПЕРСИВНЫХ МАТЕРИАЛОВ}

Прочессы классификации (разделения) сухих и влажных дисперсных материалов широко распространень в металлургии, строительстве, сельском хозяйстве, в химической, пищевой, перерабатывающей промыциленности и в других отраслях. Поэтому конструкторы и технологи большое внимание уделяют рачионализащии этих прочессов и оборудования для их реализачии в направлении повышения производительности и качества классификации, надежности машин, снижения энергоемкости. В последние десятилетия в Украине с развитием малых и средних фермерских хозяйств наблюдается тенденция увеличения разнообразия зернового сырья по видам, сортам, влажности, размерам, массе, плотности и объему частиц. Все это следует учитывать на предприятиях пищевой и перерабатывающей промышленности, которые в период сбора урожая зачастую работают в достаточно интенсивном режиме. Таким образом, в последнее время повышаются требования к эффективности технологической подготовки классификации процессов для выбора наиболее раџионального метода, оборудования и режимов обработки с учетом параметров сырья и требований последующих технологических прочессов (измельчения, перемешивания, нагревания, варки, жарки и т. д.). В связи с этим будет полезен метод автоматизированного технологического проектирования процессов классификации сухих дисперсных материалов, предлагаемый в данной статье. Метод позволяет разработать наиболее эффективную технологию классификации с учетом объема производственного задания, времени его выполнения, геометрических и структурно-механических свойств обрабатываемого материала, характеристик имеющегося оборудования для классификации и критериев эффективности разработанной технологии - производительности и заданных операционных затрат на ее реализацию. Метод может быть использован как основа для разработки компьютерной программы автоматизированного синтеза и анализа рачиональных технологических прочессов классификации зернового сырья.

Ключевые слова: классификация, автоматизированное технологическое проектирование, анализ и синтез, сухие дисперсные материаль.

Ф. 9. Puc. 1. Лum. 18.

\section{INFORMATION ABOUT THE AUTHORS}

Ivan Sevostianov - Doctor of Technical Sciences, Full Professor of the Department of "Technological Processes and Equipment of Processing and Food Productions" of Vinnytsia National Agrarian University (3 Solnechnaya St, Vinnytsia, 21008, Ukraine, e-mail: ivansev70@gmail.com, https://orcid.org/0000-0001-8965-9810).

Oleksii Tokarchuk - PhD, Associate Professor of the Department of "Technological Processes and Equipment of Processing and Food Productions" of the Vinnytsia National Agrarian University (3, Solnyshchaya St., Vinnytsia, 21008, Ukraine, e-mail: tokarchuk@ vsau.vin.ua, https://orcid.org/0000-0001-8036-1743).

Maryna Pidlypna - Post-Graduate Student of Vinnytsia National Agrarian University (3, Solnychna str., Vinnytsia, Ukraine, 21008, e-mail: petrovnamarina940@gmail.com, https://orcid.org/0000-0002-1317-2018).

Севостьянов Іван Вячеславович - доктор технічних наук, завідувач кафедри технологічних процесів та обладнання переробних і харчових виробництв Вінницького національного аграрного університету (вул. Сонячна, 3, м. Вінниця, 21008, Україна, e-mail: ivansev70@gmail.com, https://orcid.org/0000-0001-8965-9810 ). Токарчук Олексій Анатолійович - кандидат технічних наук, доцент кафедри технологічних процесів та обладнання переробних і харчових виробництв Вінницького національного аграрного університету (вул. Сонячна, 3, м. Вінниця, 21008, Україна, e-mail: tokarchuk@vsau.vin.uahttps://orcid.org/0000-0001-8036-1743).

Підлипна Марина Петрівна - аспірантка Вінницького національного аграрного університету (вул. Сонячна, 3, м. Вінниця, 21008, Україна, e-mail: petrovnamarina940@gmail.com, )

Севостьянов Иван Вячеславович - доктор технических наук, профессор кафедры «Технологических процессов и оборудования перерабатывающих и пищевых производств» Винницкого национального аграрного университета (ул. Солнечная, 3, г. Винница, 21008, Украина, e-mail: ivansev70@gmail.com, https://orcid.org/0000-0001-8965-9810).

Токарчук Алексей Анатольевич - кандидат технических наук, доцент кафедры пехнологических процессов и оборудования перерабатывающих и пищевых производств Винницкого национального аграрного университета (ул. Солнечная, 3, г.. Винница, 21008, Украина, e-mail: tokarchuk@vsau.vin.ua, https://orcid.org/0000-0001-8036-1743).

Подлипная Марина Петровна - аспирантка Винницкого национального аграрного университета (ул. Солнечная, 3, г. Винница, Винницкая область, 21008, Украина, e-mail: petrovnamarina940@gmail.com, https://orcid.org/0000-0002-1317-2018). 